\title{
JAMES PARSONS, B.Sc., F.G.S.
}

BORN JUNe 24, 1876.

Lost in Ceyion December 29, 1908.

Mr. Parsons, lately Principal Mineral Surveyor of Ceylon, has apparently lost his life under very unusual and sad circumstances. He had gone up from Colombo to Muwara Eliya for the Christmas holidays, and on December 29 went out walking in the morning, saying that he would be back for lunch. He did not return, and in spite of prolonged and careful search has not been found. It is now practically certain that he must be dead, and it appears likely that the mystery of his disappearance will never be solved.

Mr. Parsons was born June 24, 1876, was the son of James St. John Gage Parsons, F.R.C.S., of Bristol, and was educated at University College, Bristol, and afterwards at University College, London, where he attended Professor Bonney's classes. Appointed in 1903 as Assistant Director of the Mineralogical Survey, temporarily established by the Ceylon Government, he did excellent work in investigating the mineral resources of Ceylon, his results being incorporated in the Annual Reports of the Survey. When in 1908 the Survey was continued for a further three years, Mr. Parsons was appointed Principal Mineral Surveyor in succession to the Director, who retired. In 1907-8 he acted in this capacity, his reports being published annually.

Mr. Parsons was the author of a paper on "Development of Brown Mica from Augite", published in these pages in 1900, and of a paper on "Quartz in Ceylon", published in Spolia Zeylanica for 1908. His "Administration Report" for 1907 has just been issued. He had other work in preparation. He was a close personal friend of the writer. His loss will be keenly felt, for in addition to his geological work he was greatly interested in Oriental philosophy and in Sinhalese folklore. He was fairly proficient in Sinhalese, and was on the best of terms with his staff. He was at one time Secretary of the Bristol Branch of the Theosophical Society, and had made some study of Sanskrit. He was a man who cannot be easily replaced.

Great s5mpathy will be felt for his wife, who was with him in Muwara Eliya at the time of his disappearance, and for his family in Bristol. It is a consolation to reflect that he now, perhaps, knows something more of that psychology and philosophy which formed his deepest interest.

A. .K. Coomarasteami.

MISOEIIANEOUS.

Mineralogy in Oxford. - The vacancy in the Waynflete professorship of Mineralogy at Oxford, caused by the appointment of Professor H. A. Miers as Principal of the University of London, has been filled by the promotion of Mr. H. L. Bowman, M.A., F.G.S., who has acted for some years as demonstrator in mineralog $y$ under Professor Miers. 